\title{
PENGUJIAN KEKUATAN RIG UNTUK UJI TARIK BAJA A36 DIAMETER 30 MM BENTUK STANDARD DENGAN ANALISA SOFTWARE SOLIDWORK
}

\author{
ELLYSA KUSUMA LAKSANAWATI ${ }^{1)}$ \& ALVIN ADHITA GUNAWAN ${ }^{2)}$ \\ Program Studi Teknik Mesin, Fakultas Teknik, Universitas Muhammadiyah Tangerang \\ Jl. Perintis Kemerdekaan I/33 Cikokol-Tangerang \\ Email: ellysakl@yahoo.com ${ }^{1)}$,alvinadhita95@gmail.com ${ }^{2)}$
}

\begin{abstract}
ABSTRAK
Pengujian Rig dengan Besi Beton A36 dilakukan sesuai dengan penggunaan dilapangan sebagai struktur pada bangunan. Biasanya yang menjadi fokus perhatian adalah kemampuan maksimum bahan tersebut dalam menahan beban. Metode yang dilakukan untuk mengetahui kekuatan rig, apakah mampu menahan kekuatan uji tarik statis baja A36 yang diberi beban uji sebesar $200 \mathrm{kN}$ adalah selain melalui pengujian dilapangan juga dengan menggunakan software solidwork's 2013. Pengujian dan analisa dilakukan di Balai Besar Teknologi Kekuatan Struktur (B2TKS) yang bertempat di kawasan PUSPITEK Serpong Tangerang Gedung 220. Dari hasil pengujian di Balai Besar Teknologi Kekuatan Struktur dan analisa menggunakan software solidwork 2013 yang dilakukan, bahwa Rig yang diuji mampu menahan kekuatan uji tekan statis Baja A36.
\end{abstract}

Kata Kunci: Baja Beton A36, Uji Tekan Statis, Rig, software Solidwork's 2013, Beban Uji 200 kN.

\section{PENDAHULUAN}

Kekuatan tarik atau kekuatan tarik maksimum (ultimate tensile strength) adalah nilai yang paling sering dituliskan sebagai hasil suatu uji tarik, tetapi pada kenyataan-nya nilai tersebut kurang bersifat mendasar dalam kaitannya dengan kekuatan material. Untuk logam ulet, kekuatan tariknya harus dikaitkan dengan beban maksimum, dimana logam dapat menahan beban sumbu untuk keadaan yang sangat terbatas

Pengujian besi beton dilakukan sesuai dengan penggunaan dilapangan, karena Besi Beton yang diuji akan digunakan sebagai struktur pada Bangunan. Penelitian dilakukan untuk mengetahui kekuatan Rig uji tarik baja A36 dimana umumnya baja A36 ini banyak dipakai pada konstruksi bangunan dan jembatan, maka dilakukan dengan menggunakan metode uji statis uji tekan. Dimana pada saat pengujian beban uji tekan statis yang diberikan pada uji statis besi beton adalah $200 \mathrm{kN}$ (80\% dari kapasitas actuator $250 \mathrm{kN}$.)
Dengan demikian maka perlu dilakukan analisa kekuatan pada palang (glagar) tersebut agar kuat untuk melakukan pengujian dengan kapasitas $200 \mathrm{Kn}$. Selain untuk mengetahui batas yield baja A36 diameter 30 $\mathrm{mm}$. Analisa juga dilakukan dengan menggunakan software solidwork's 2013.

Untuk mengetahui sifat-sifat suatu bahan, tentu kita harus mengadakan pengujian terhadap bahan tersebut. Ada empat jenis uji coba yang biasa dilakukan, yaitu uji tarik (tensile test), uji tekan (compression test), uji torsi (torsion test), dan uji geser (shear test). Dalam tulisan ini kita akan membahas tentang uji tarik dan sifat-sifat mekanik logam yang didapatkan dari interpretasi hasil uji tarik.

Uji tarik mungkin adalah cara pengujian bahan yang paling mendasar. Pengujian ini sangat sederhana, tidak mahal dan sudah mengalami standarisasi di seluruh dunia, misalnya di Amerika dengan ASTM E8 dan Jepang dengan JIS 2241. Dengan menarik suatu bahan kita akan segera mengetahui 
bagaimana bahan tersebut bereaksi terhadap tenaga tarikan dan mengetahui sejauh mana material itu bertambah panjang. Alat eksperimen untuk uji tarik ini harus memiliki cengkeraman (grip) yang kuat dan kekakuan yang tinggi (highly stiff). Brand terkenal untuk alat uji tarik antara lain adalah antara lain adalah Shimadzu, Instron dan Dartec.

\section{a. Uji Tarik}

Banyak hal yang dapat kita pelajari dari hasil uji tarik. Bila kita terus menarik suatu bahan (dalam hal ini suatu logam) sampai putus, kita akan mendapatkan profil tarikan yang lengkap yang berupa kurva seperti digambarkan pada Gambar 1. Kurva ini menunjukkan hubungan antara gaya tarikan dengan perubahan panjang. Profil ini sangat diperlukan dalam desain yang memakai bahan tersebut.

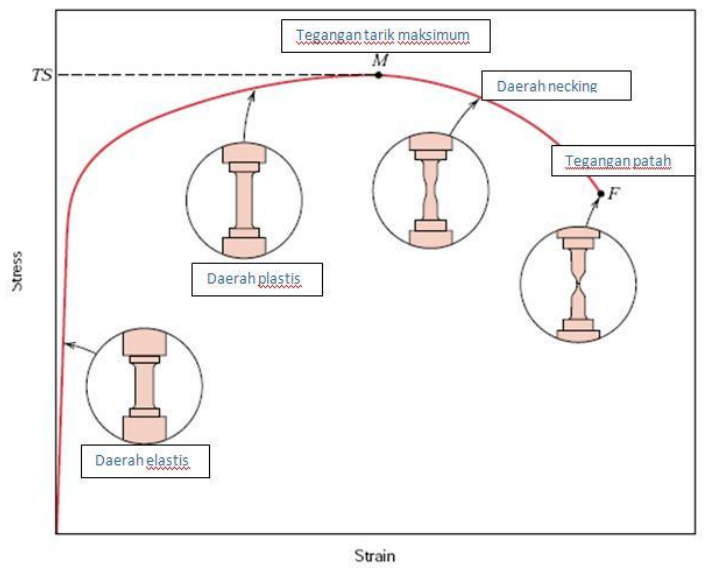

Gambar 1. Gambaran Singkat Uji Tarik Dan Datanya. Sumber:

http://download.portalgaruda.org/article.php?article= $\underline{1080501 \& \mathrm{val}=1011}$

Biasanya yang menjadi fokus perhatian adalah kemampuan maksimum bahan tersebut dalam menahan beban. Kemampuan ini umumnya disebut "Ultimate Tensile Strength" disingkat dengan UTS, dalam bahasa Indonesia disebut tegangan tarik maksimum.

\section{Hukum Hooke (Hooke's Law)}

Untuk hampir semua logam, pada tahap sangat awal dari uji tarik, hubungan antara beban atau gaya yang diberikan berbanding lurus dengan perubahan panjang bahan tersebut. Ini disebut daerah linier atau linear zone. Di daerah ini, kurva pertambahan panjang vs beban mengikuti aturan Hooke yakni rasio tegangan (stress) dan regangan (strain) adalah konstan. Stress adalah beban dibagi luas penampang bahan dan strain adalah pertambahan panjang dibagi panjang awal bahan.

1. Stress: $\sigma=F / A$

Dimana $=\mathrm{F}$ : gaya tarikan $(\mathrm{kN})$

A: luas penampang $(\mathrm{mm})$.

2. Strain: $\varepsilon=\Delta \mathrm{L} / \mathrm{L}$

Dimana $=\Delta \mathrm{L}$ : pertambahan panjang (mm)

$$
\text { L: panjang awal (mm). }
$$

Hubungan antara stress dan strain dirumuskan:

$$
(\mathrm{E}=\sigma / \varepsilon)
$$

Dimana:E $=$ Gradien Kurva Dalam Daerah Linier

$$
\begin{aligned}
& \sigma=\text { Perbandingan Tegangan } \\
& \varepsilon=\text { Regangan }
\end{aligned}
$$

Untuk memudahkan pembahasan, Gambar 1. kita modifikasi sedikit dari hubungan antara gaya tarikan dan pertambahan panjang menjadi hubungan antara tegangan dan regangan (stress vs strain). Selanjutnya kita dapatkan Gambar 2. yang merupakan kurva standar ketika melakukan eksperimen uji tarik. E adalah gradien kurva dalam daerah linier, dimana perbandingan tegangan $(\sigma)$ dan regangan $(\varepsilon)$ selalu tetap. E diberi nama "Modulus Elastisitas" atau "Young Modulus". Kurva yang menyatakan hubungan antara strain dan stress seperti ini kerap disingkat kurva SS (SS curve).

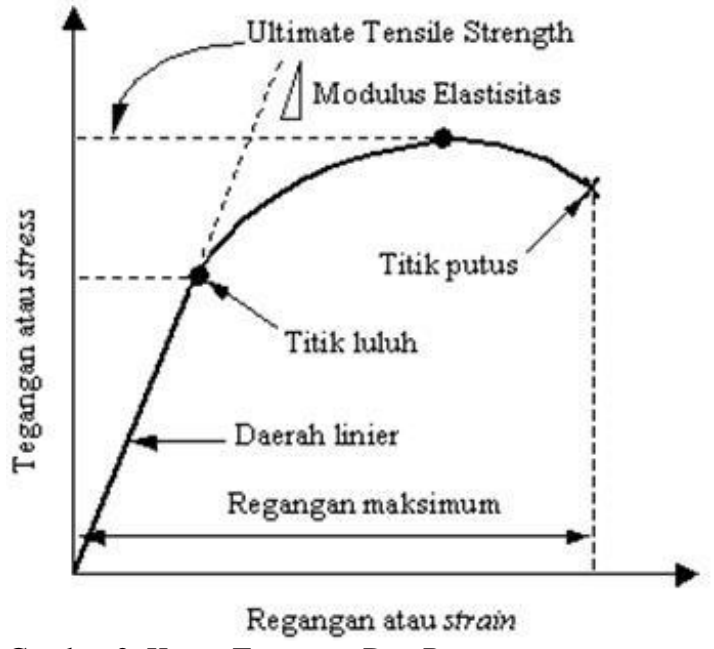

Gambar 2. Kurva Tegangan Dan Regangan.

Sumber:

https://rudydwi.wordpress.com/2010/03/28/mengetahui -sifat-mekanik-material-dengan-uji-tarik/ 


\section{Solidwork}

Solidworks adalah salah satu software yang digunakan untuk merancang part permesinan atau susunan part pemesinan yang berupa assembling dengan tampilan $3 \mathrm{~d}$ untuk mempresentasikan part sebelum real partnya dibuat atau tampilan 2D (drawing) untuk gambar proses pemesinan.

\section{Solid Work Model (Templates )}

Didalam membuat suatu pemodelan 3D menggunakan Solidwork 2013, maka tahapan awal yang kita buat adalah membuat sketsa gambar dari object desain atau model yang akan kita buat. Proses pembuatan sketsa secara umum dilakukan pada bidang( Plane ) front Plane, dan Right Plane, atau bisa juga pada bidang tertentu lainnya tergantung kepada bagian fitur-fitur dari obyek desain yang akan kita buat.proses sketsa dengan sketch entilities atau sketch toolbar, untuk melakukan proses peng-sketsaan menggunakan sketch Entilities atau sketch tool dapat dilakukan dengan tahapan proses sebagai berkut.

Klik Sketch pada command Manager untuk memunculkan Sketch toolbar, Gambar 3.

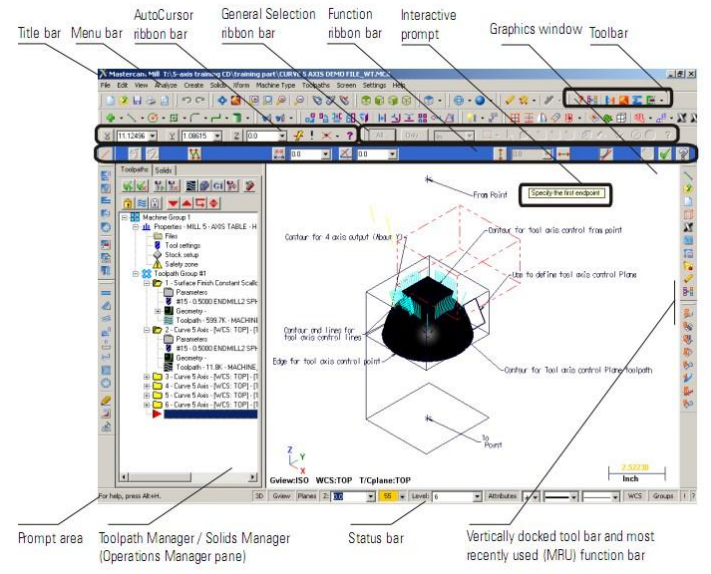

Gambar 3. Fitur Dari Solidwork.

Sumber: Software Solidworks 2013.

Didalam proses pembuatan sketsa, kita diminta untuk menentukan bidang (Plane) dimana kita akan memulai proses pengsketsaan. Pada SolidWork2013 secara umum ada 3 bidang yang menjadi acuan bagi kita dalam membuat sketsa atau proses pemodelan yaitu Front, Top, Right.

Ketika kita meng-klik salah satu perintah pada sketch toolbar maka secara otomatis kita akan diminta untuk menentukan bidang (plane) yang menjadi acuan. Didalam teori mekanikal engineering design bidang acuan ini bisa diartikan sebgai bentuk pandangan dari suatu obyek desain. tampilan perintah yang diminta oleh program solidwork untuk menentukan bidang gambar sketsa dapat dilihat pada gambar berikut.

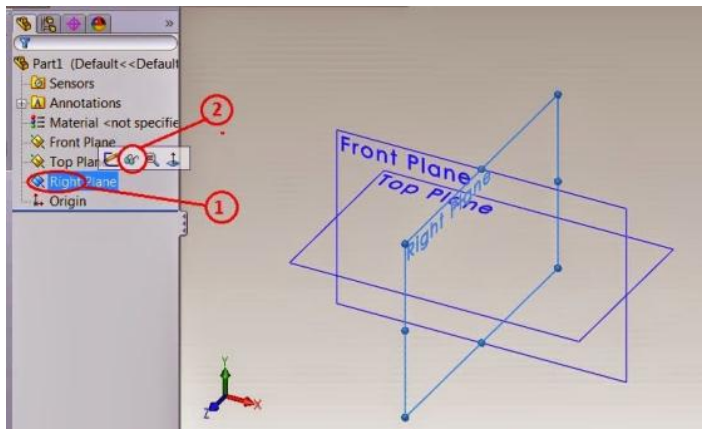

Gambar 4. Bidang Kerja Pada Solidwork

Sunber: Software Solidworks 2013.

Setelah kita menentukan bidang gambar yang akan kita jadkan acuan maka kita sudah dapat memulai proses pengsketsaan.proses sketsa dibagi menjadi:

1. Sketsa dalam format 2D

2. Sketsa dalam format $3 \mathrm{D}$

Pada proses pengsketsaan didalam format 2D kita menggunakan acuan sumbu $\mathrm{x}$ dan sumbu y, sedangkan pada format 3D kita menggunakan acuan sumbu $x$, sumbu y dan sumbu z.

Proses pengsketsaan selalu diikuti oleh tahapan pemberian dimensi dimana prose pemberian dimensi tersebut dapat kita lakukan dengan mengisi nilai dimensi pada kotak dialog Feature Nabager Design Tree atau bisa juga dengan meng-klik smart dimensin pada sketch toolbar dan kemudian klik garis sketsa yang ingin diberikan nilai dimensi.

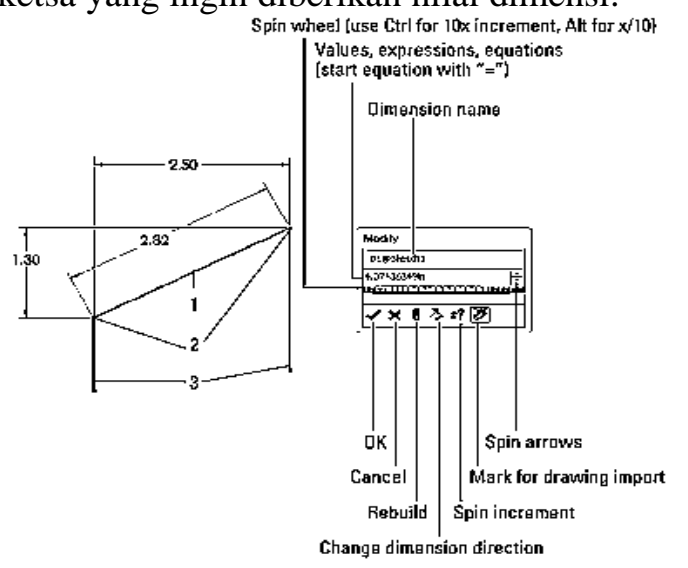

Gambar 5. Aplikasi Peng-Sketsaan dan PenDimensian.

Sumber: Software Solidworks 2013. 


\section{HASIL PENELITIAN DAN PEMBA-} HASAN

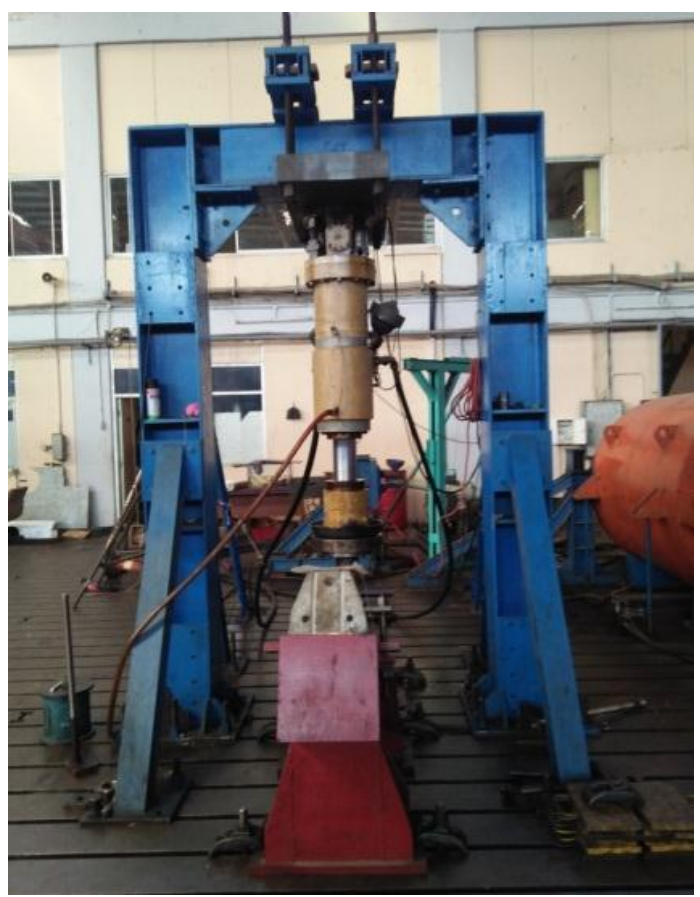

Gambar 6. Bentuk Rig $250 \mathrm{kN}$.

Sumber: Balai Besar Teknologi Kekuatan Struktur (B2TKS).

Komponen Peralatan Pengujian:

1. Bentuk Dan Dimensi Palang (Glagar).

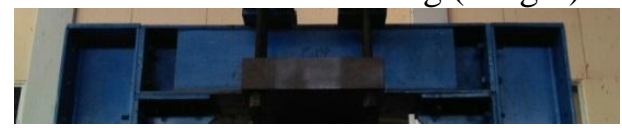

Gambar 7. Bentuk Palang (Gelagar).

Sumber: Balai Besar Teknologi Kekuatan Struktur (B2TKS).

2. Bentuk dan Dimensi Tiang.

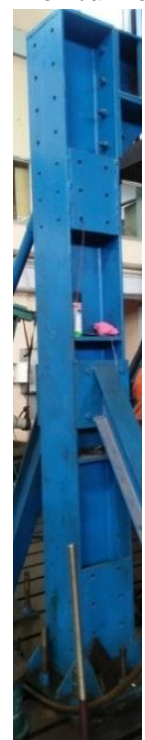

Gambar 8. Bentuk Tiang.

Sumber: Balai Besar Teknologi Kekuatan Struktur (B2TKS).
3. Bentuk dan Dimensi Penjepit Atas.

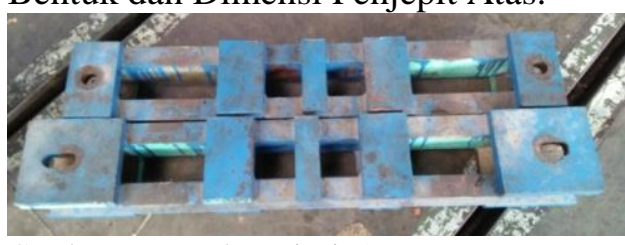

Gambar 9. Bentuk Penjepit Atas.

Sumber: Balai Besar Teknologi Kekuatan Struktur (B2TKS).

4. Bentuk dan Dimensi Baut Pengikat.

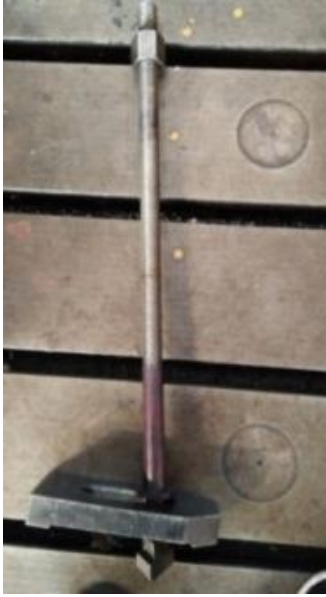

Gambar 10. Bentuk Baut Pengikat

Sumber: Balai Besar Teknologi Kekuatan Struktur (B2TKS).

5. Bentuk dan Dimensi Baut Penjepit.

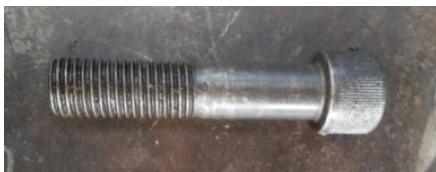

Gambar 11. Bentuk Baut Penjepit.

Sumber: Balai Besar Teknologi Kekuatan Struktur (B2TKS).

6. Bentuk dan Dimensi Dudukan Actuator.

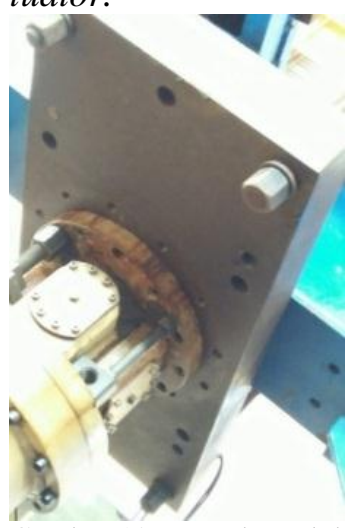

Gambar 12. Bentuk Dudukan Actuator.

Sumber: Balai Besar Teknologi Kekuatan Struktur (B2TKS) 
7. Bentuk dan Dimensi Cross Joint.

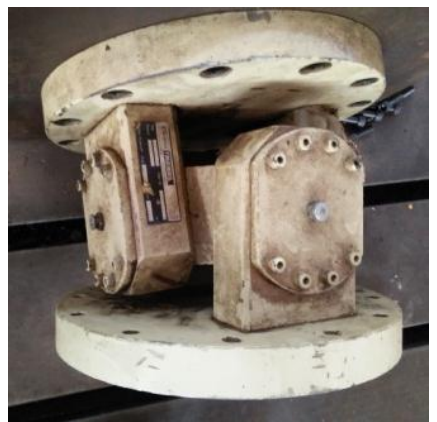

Gambar 13. Bentuk Cross Joint.

Sumber: Balai Besar Teknologi Kekuatan Struktur (B2TKS).

8. Bentuk dan Dimensi Actuator $250 \mathrm{kN}$.

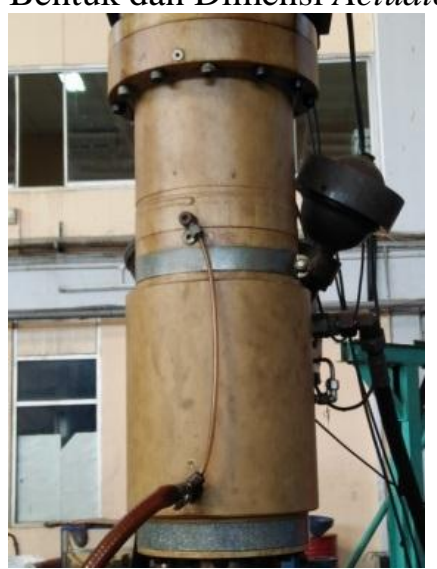

Gambar 14. Bentuk Actuator.

Sumber: Balai Besar Teknologi Kekuatan Struktur (B2TKS).

9. Bentuk dan Dimensi Interface 1 .

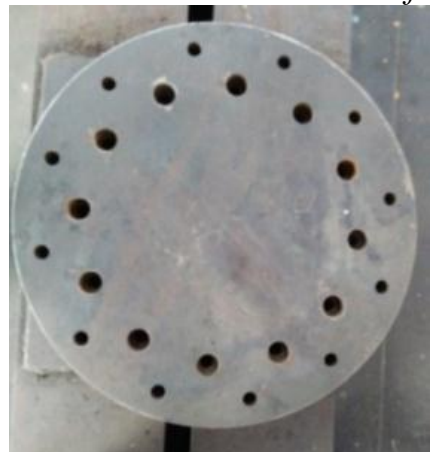

Gambar 15. Bentuk Interface 1.

Sumber: Balai Besar Teknologi Kekuatan Struktur (B2TKS).
10. Bentuk dan Dimensi Loadcell.

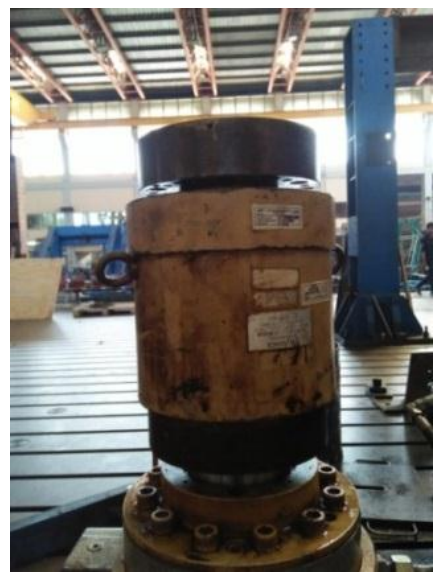

Gambar 16. Bentuk Loadcell.

Sumber: Balai Besar Teknologi Kekuatan Struktur (B2TKS).

11. Bentuk dan Dimensi Interface 2.

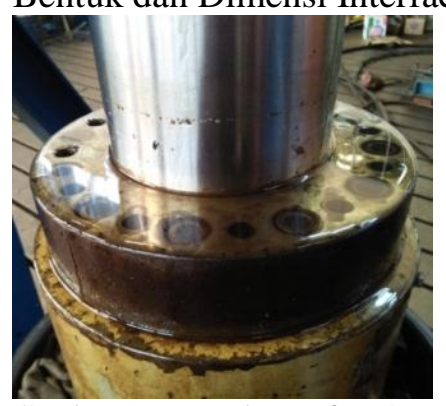

Gambar 17. Bentuk Interface 2

Sumber: Balai Besar Teknologi Kekuatan Struktur (B2TKS).

12. Bentuk dan Dimensi Alat Bantu Benda Uji.

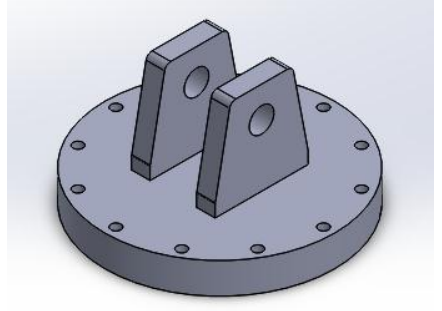

Gambar 18. Bentuk Alat Bantu Benda Uji .

Sumber: Balai Besar Teknologi Kekuatan Struktur (B2TKS).

13. Bentuk, Dimensi Benda Uji dan Material Property.

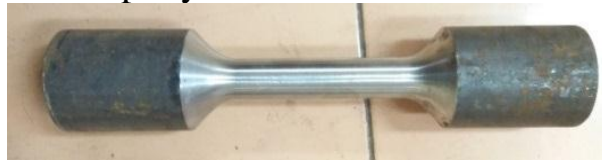

Gambar 19. Bentuk Benda Uji .

Sumber: Balai Besar Teknologi Kekuatan Struktur (B2TKS). 
Tabel 1.Material Properties ASMI A36.

\begin{tabular}{|l|l|l|}
\hline Property & Value & Units \\
\hline Elastic Modulus & $2 \mathrm{e}+011$ & $\mathrm{~N} / \mathrm{m}^{\wedge} 2$ \\
\hline Poissons Ratio & 0.26 & $\mathrm{~N} / \mathrm{A}$ \\
\hline Shear Modulus & $7.93 \mathrm{e}+010$ & $\mathrm{~N} / \mathrm{m}^{\wedge} 2$ \\
\hline Density & 7850 & $\mathrm{~kg} / \mathrm{m}^{\wedge} 3$ \\
\hline Tensile Strength & 400000000 & $\mathrm{~N} / \mathrm{m}^{\wedge} 2$ \\
\hline Compressive Strength in X & & $\mathrm{N} / \mathrm{m}^{\wedge} 2$ \\
\hline Yield Strength & 250000000 & $\mathrm{~N} / \mathrm{m}^{\wedge} 2$ \\
\hline Thermal Expansion Coefficient in X & & $\mathrm{K}$ \\
\hline Thermal Conductivity in X & & W/(m-K) \\
\hline
\end{tabular}

Sumber:Software Solidworks 2013.

14. Bentuk dan Dimensi Dudukan Benda Uji.

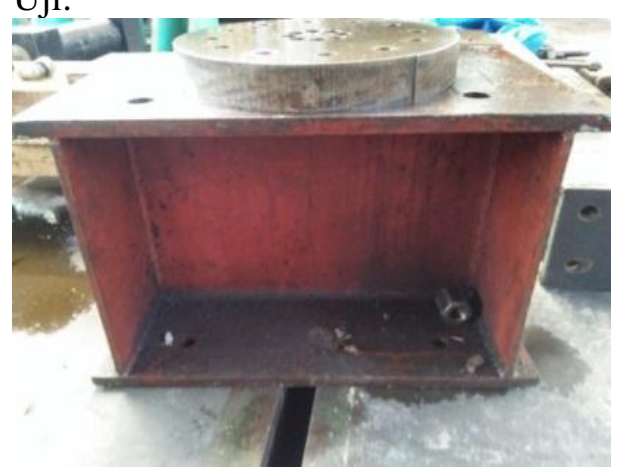

Gambar 20. Bentuk Dudukan Benda Uji.

Sumber: Balai Besar Teknologi Kekuatan Struktur (B2TKS).

\section{Analisa Gaya Pengujian}

Untuk menentukan besarnya gaya pengujian (Akuator) yang akan digunakan dilakukan melalui analisa kekuatan tarik yang dibutuhkan untuk menguji kekuatan benda uji sampai melewati batas yield.

$\sigma_{\max }=\frac{F}{A}$

Persamaan 1.

Dimana untuk mencari gaya yang akan bekerja saat pengujian pada software solidworks didapatkan.

Jika dilihat persamaan 1 didapatkan bahwa:

$$
\begin{aligned}
\sigma_{\max } & =\frac{F}{A} \\
\mathrm{~F} & =\sigma_{y} \cdot A
\end{aligned}
$$

Dimana:

$\sigma_{\max }=$ Tegangan Maksimal.

$\mathrm{F}=$ Gaya.

$\sigma_{y}=$ Tegangan Yield

$\mathrm{A}=$ Luas Penampang.

Bahan untuk benda uji memiliki material properties sesuai dengan standart ASMI A36, dengan

$$
=250 \mathrm{~N} / \mathrm{mm}^{2} \cdot \frac{\pi}{4}(30)^{2} \mathrm{~mm}^{2}
$$$$
=176625 \mathrm{~N} \Leftrightarrow 176,625 \mathrm{kN}
$$

Jadi beban uji yang dibutuhkan untuk pengujian hingga benda uji mengalami kerusakan (yield) adalah sebesar 176.625 $\mathrm{kN}$.

Kemudian dilakukan pemodelan dengan menggunakan software solidworks dan dihasilkan analisa kekuatan sebagai berikut:

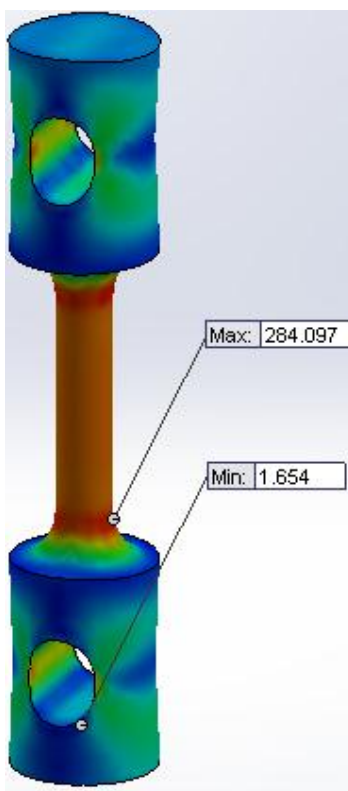

von Mises (Nimm² (MPa))

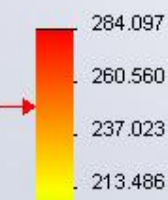

213.486

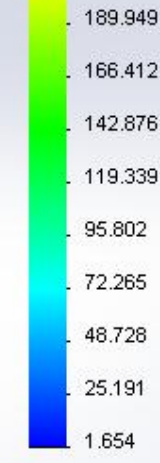

$\rightarrow$ Yield strength: 250.000

Gambar 21. Analisa Kekuatan Benda Uji Dengan Beban Uji $176.625 \mathrm{kN}$.

Sumber: Software Solidworks 2013.

Pada simulasi ini bahan benda uji diambil dari material ASTM A36 STEEL dengan tegangan patah $400 \mathrm{~N} / \mathrm{mm}^{2}$ dan tegangan luluh atau yield strees $250 \mathrm{~N} / \mathrm{mm}^{2}$ diperoleh hasil sebagai berikut, benda uji sudah patah atau rusak karena tegangan yang terjadi di atas yield.

Berhubung mesin uji yang tersedia memiliki kapasitas uji sebesar $250 \mathrm{kN}$ dan beban uji yang diijinkan hanya $80 \%$ kapasitas mesin uji maka beban uji yang digunakan pada mesin ini $80 \%$ x $250=200 \mathrm{kN}$.

1. Pemeriksaan Kekuatan Komponen Pengujian Terhadap Beban Uji.

Untuk mengetahui kondisi benda uji dengan beban uji $200 \mathrm{KN}$ maka dilakukan simulasi pengujian dengan menggunakan software solidworks. Dan hasil pemodelan seperti gambar dibawah ini: 

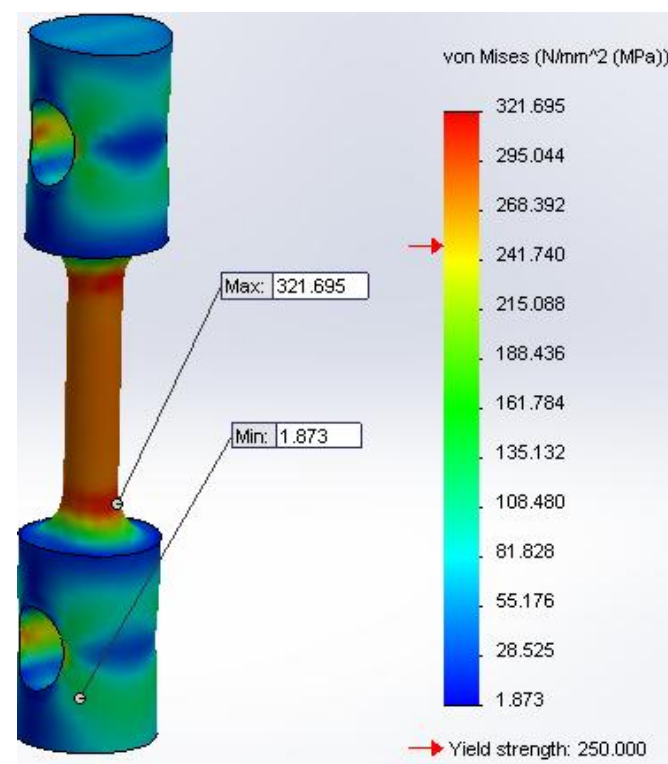

Gambar 22. Analisa Kekuatan Benda Uji Dengan Beban Uji $200 \mathrm{kN}$.

Sumber: Software Solidworks 2013.

Dari hasil pemodelan ternyata benda uji telah mengalami kerusakan karena yang terjadi pada daerah uji sebesar 321.695 $\mathrm{N} / \mathrm{mm}^{2}$ lebih besar dibandigkan dengan kekuatan yield dari bahan benda uji (250 $\mathrm{N} / \mathrm{mm}^{2}$ ).

2. Analisa Kekuatan Alat Bantu Pengujian.

Untuk analisa kekuatan alat bantu pengujian (fitting double lug) beban uji yang diberikan adalah $200 \mathrm{kn}$, dan material properties sesuai dengan ASTM A36. Hasil pemodelan dapat dilihat seperti dibawah ini:

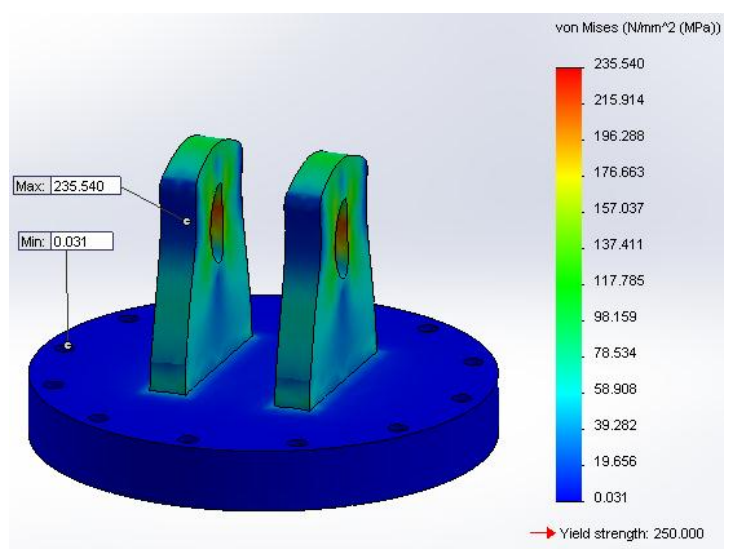

Gambar 23. Analisa Kekuatan Alat Bantu Benda Uji Dengan Beban Uji 200 kN.

Sumber:Software Solidworks 2013.

Dari hasil analisa kekuatan ,ternyata beban yang diterima sebesar 235.540
$\mathrm{N} / \mathrm{mm}^{2}$, tidak melebihi batas yield bahan sebesar $250 \mathrm{~N} / \mathrm{mm}^{2}$.

3. Analisa Kekuatan Palang (Glagar).

Gambar 24. Analisa Kekuatan Palang.

Sumber:Software Solidworks 2013.

Dari hasil analisa kekuatan palang (glagar) ternyata beban yang diterma oleh palang sebesar $151.349 \mathrm{~N} / \mathrm{mm}^{2}$, tidak melebihi batas yield bahan sebesar 250 $\mathrm{N} / \mathrm{mm}^{2}$.

4. Analisa Kekuatan Tiang.

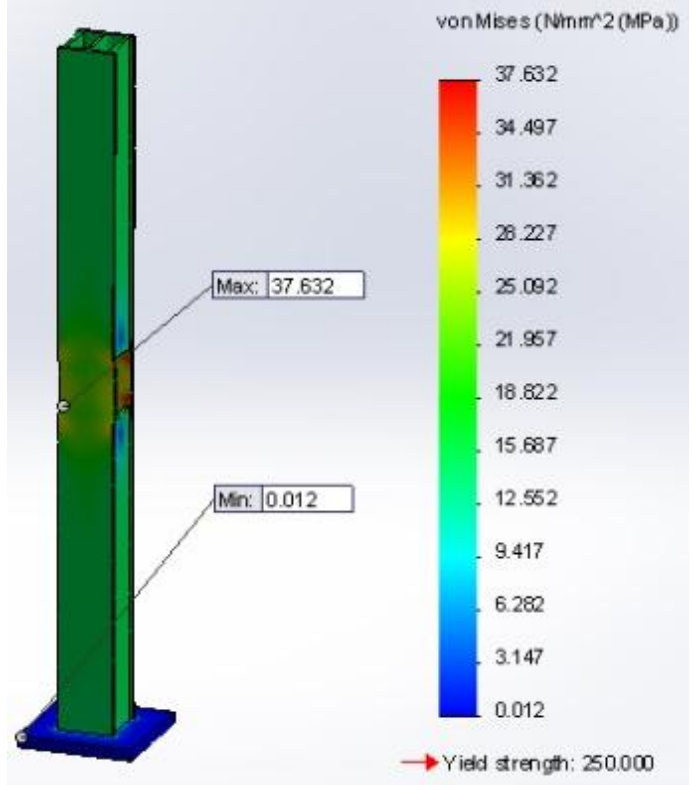

Gambar 25. Analisa Kekuatan Tiang.

Sumber:Software Solidworks 2013.

Dari hasil analisa kekuatan tiang ternyata beban yang diterima oleh palang sebesar $37.632 \mathrm{~N} / \mathrm{mm}^{2}$, tidak melebihi batas yield bahan sebesar $250 \mathrm{~N} / \mathrm{mm}^{2}$.

\section{Analisa Kekuatan Baut M16.}

Tegangan kerja yang diterima oleh baut pengikat M16 adalah:

$\sigma_{\mathrm{t}}=\frac{\frac{f}{z}}{A}=\frac{\frac{f}{z}}{\frac{\pi}{8} x d 1^{2}}$ 
dimana:

$\sigma_{\mathrm{t}} \quad=$ tegangan tarik yang diterima oleh baut akibat pengujian. $\left(\mathrm{N} / \mathrm{mm}^{2}\right)$

$f \quad=$ beban pengujian $(\mathrm{N})$

$z \quad=$ jumlah baut M16

$\mathrm{A}=$ luas penampang baut yang menerima beban

$\pi \quad=$ jari-jari

$\mathrm{d} 1^{2}=$ diameter baut terluar

Dimensi baut yang telah diketahui dari dimensi baut $\varnothing 16 \times 1.5$, dan nilai Kelas 10.9, berdasarkan Table 2. bilangan kekuatan baut/skrupmesin dan baut., tegangan maksimum (break) $(\sigma b)=120 \mathrm{~kg} / \mathrm{mm}^{2}$, jika di konversikan menjadi $1200 \mathrm{~N} / \mathrm{mm}^{2}$.

6. Analisa Kekuatan Baut Penjepit (M16). Beban uji $(f)$ adalah

$\sigma \mathrm{n}=\frac{\frac{f}{z}}{A}=\frac{\frac{f}{z}}{\frac{\pi}{4} x d 1^{2}}=\frac{\frac{200000 \mathrm{~N}}{8 \text { buah }}}{\frac{\pi}{4} \times 13.835 \mathrm{~mm}^{2}}=$ $\frac{25000 \mathrm{~N}}{150.25 \mathrm{~mm}^{2}}=166.4 \mathrm{~N} / \mathrm{mm}^{2}$

Diperoleh kekuatan tarik maksimum untuk baut kelas 10.9 adaalah sebesar 1200 $\mathrm{N} / \mathrm{mm}^{2}$, dengan demikian maka baut cukup aman untuk menerima beban kerja karena tegangan yang terjadi $(\sigma n)$ lebih kecil dari $1200 \mathrm{~N} / \mathrm{mm}^{2}$

7. Analisa Kekuatan Baut Pengikat (M20). $\begin{aligned} \sigma \mathrm{n} & =\frac{\frac{200000 \mathrm{~N} / \mathrm{mm} 2}{12 \mathrm{buah}}}{\frac{\pi}{4} \times 17,294 \mathrm{~mm}^{2}}=\frac{16666 \mathrm{~N}}{234.77 \mathrm{~mm}^{2}} \\ & =70.98 \mathrm{~N} / \mathrm{mm}^{2}\end{aligned}$

Diperoleh kekuatan tarik maksimum untuk baut kelas 10.9 adaalah sebesar 1200 $\mathrm{N} / \mathrm{mm}^{2}$, dengan demikian maka baut cukup aman untuk menerima beban kerja karena tegangan yang terjadi $(\sigma n)$ lebih kecil dari $1200 \mathrm{~N} / \mathrm{mm}^{2}$.

8. Analisa Kekuatan Baut Pengikat
(M30).
Dengan menggunakan data yang telah diketahui dari dimensi baut $\emptyset 30 \times 1.5$ Dengan data diatas maka dapat kita hitung dengan perhitungan di bawah ini untuk mencari tegangan tarik pada baut M30.

Bahan untuk baut M30 adalah asab dengan tegangan yield sebesar $705 \mathrm{~N} / \mathrm{mm}^{2}$ sedangkan allowable stress (tegangan yang di ijinkan) sebesar:

$2 / 3 \times 705 \mathrm{~N} / \mathrm{mm}^{2}=470 \mathrm{~N} / \mathrm{mm}^{2}$

Tegangan yang terjadi pada baut M30 pada saat pengujian adalah:

$$
\begin{aligned}
\sigma \mathrm{n} & =\frac{\frac{f}{z}}{A}=\frac{\frac{f}{z}}{\frac{\pi}{4} \times d 1^{2}} \\
\sigma \mathrm{n} & =\frac{\frac{200000 \mathrm{~N} / \mathrm{mm}^{2}}{8 \mathrm{buah}}}{\frac{\pi}{4} \times 26.211 \mathrm{~mm}^{2}}=\frac{25000 \mathrm{~N}}{539.31 \mathrm{~mm}^{2}} \\
& =46.35 \mathrm{~N} / \mathrm{mm}^{2}
\end{aligned}
$$

Dari hasil perhitungan diatas diperoleh tegangan yang terjadi lebih kecil dibanding dengan tegangan uji dari baut $\left(46.35 \mathrm{~N} / \mathrm{mm}^{2}\right.$ $<470 \mathrm{~N} / \mathrm{mm}^{2}$ ).

\section{KESIMPULAN}

Dari hasil pengujian dan analisa yang telah dilakukan dengan software solidworks, dapat diambil kesimpulan sebagai berikut:

1. Benda uji telah mengalami kerusakan karena yang terjadi pada daerah uji sebesar $321.695 \mathrm{~N} / \mathrm{mm}^{2}$ lebih besar dibandingkan dengan kekuatan yield dari bahan benda uji $\left(250 \mathrm{~N} / \mathrm{mm}^{2}\right)$.

2. Rig dinyatakan kuat dimana, Palang (Glagar), tiang dan baut kuat untuk melakukan pengujian dengan beban 200 $\mathrm{kN}$ dan untuk menopang actuator.

\section{DAFTAR PUSTAKA}

Alla Rechete Vorbehallen 1971. Buku "DESAIN ACTUATOR" By. CARL SCHENCK AG Germany.

http://download.portalgaruda.org/article.ph p? article $=1080501 \&$ val $=1011$

http://ojs.umsida.ac.id/index.php/rem/index

https://rudydwi.wordpress.com/2010/03/28/ mengetahui-sifat-mekanik-materialdengan-uji-tarik/

Krist, 1972, "FORMELN UND TABELLEN" Fur Das Bauwesen Hoch -Und Stahlbau, Germany: by TecknikTabellen-Verlang Fikentscher \& Co.

Sularso Dan Kiyokatsu Suga . 1985. Dasar Perencanaan Dan Pemilihan Elemen Mesin. Jakarta: PT. Pradnya Pramita.

Takeshi Sato G dan N Sugiarto H. 1992. Menggambar Mesin, Jakarta: PT. Pradya Paramita. 